\title{
Diurnal kinetics of mammary oxygen uptake in dairy cows
}

\author{
J Guinard, H Rulquin
}

INRA, Station de Recherches sur la Vache Laitière, 35590 Saint-Gilles, France

The diurnal kinetics of mammary arterio-venous differences show opposite trends between glucose and acetate concentrations (Rulquin, 1983), though milk secretion rate is assumed to be constant between milkings. Changes in the udder oxidative metabolism can thus be presumed. The aim of this study was to test whether diumal variations in oxygen consumption and extraction rate were also noted in the udder.

Three Holstein cows in late lactation $(22.5 \mathrm{~kg}$ milk/d) were both fed and milked at $6 \mathrm{~h} 00$ and $18 \mathrm{~h} 00$. The ration (corn silage $61 \%$; concentrate $29 \%$; and dehydrated alfalfa $10 \%$, on DM basis) was calculated to meet the energy and protein requirements. Kinetics of oyxgen uptake by the mammary gland were studied in two $12 \mathrm{~h}$ periods at a $19 \mathrm{~d}$ interval. Six blood samples (see fig 1) were collected simultaneously from catheters in the left carotid and subcutaneous abdominal vein. Total oxygen was measured by a gas analyser coupled with a hemoxymeter. Mammary blood flow was determined continuously but averaged on 30 min intervals, using an ultrasonic probe implanted around the left external pudic artery. The mammary extraction rate $([A]-[V M / A] \times 100)$ and the consumption $([A]-[V]$ $x$ blood flow) were analysed by a model of variance analysis (cow $x$ period) with a repeated measure model on sampling time (SAS).

The arterial oxygen concentration did not vary significantly with time (fig 1 ). In contrast, the extraction rate was maximum at $40 \%$ after $2 \mathrm{~h}$ and then fell to $28 \%(P<0.05)$. The blood flow varied inversely to the extraction rate (within-cow $r^{2}=0.43, P<0.01$ ); therefore the mammary oxy-

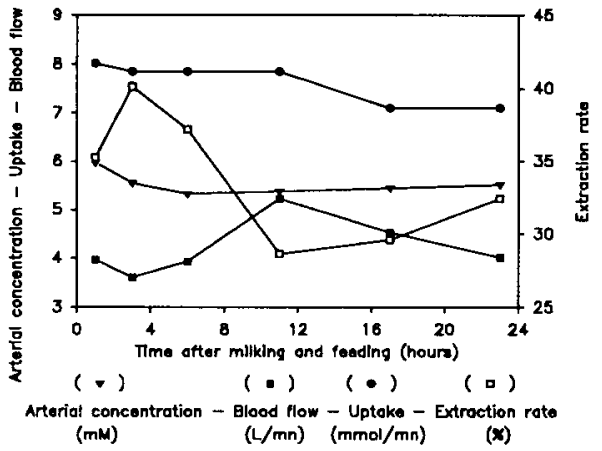

Fig 1. Arterial concentration, extraction rate and consumption of oxygen by the half udder of lactating cows.

gen consumption remained relatively constant between milkings (fig 1). A similar compensatory mechanism between blood flow and tissue ability to extract oxygen was also observed for human brain (Chollet and Frackowiack, 1991). In conclusion, the steady state observed for mammary oxygen consumption would agree with that generally assumed for milk secretion; it could possibly mean that the nature of oxidative substrates varies as the profile of nutrient uptake changes during the day.

Chollet F, Frackowiak RSJ (1991) Livest Prod Sci $27,35-41$

Rulquin H (1983) Reprod Nutr Dev23, 1029-1042 